\title{
Szabó Tamás
}

\section{A területi versenyképesség és a közszolgáltatások hozzáférhetôségének kapcsolata}

\section{Correlations Between Regional Competitiveness and Access to Public Services}

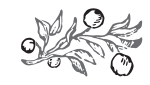

\section{Összefoglalás}

A területi versenyképesség meghatározható úgy is, mint az adott térség azon képessége, amely révén vonzóvá válik a betelepülő tôke számára, illetve ennek révén a lakosság elöregedése és elvándorlása ellen hat. E logika mentén a fenntartható versenyképességet a fenntartható infrastruktúra, az elérhetô közszolgáltatások és a vonzó életkörnyezet vizsgálatával tudjuk értékelni, és megállapítani, hogy társadalmi kontextusban milyen mértékben befolyásolják a vizsgált térségek gazdasági eredményességét. Jelen tanulmány négy magyarországi megye területi versenyképességének összehasonlítására vállalkozik, azok gazdasági, társadalmi, infrastrukturális, valamint az egyes közszolgáltatások hozzáférhetőségének jellemzői mentén. Az alkalmazott módszertan tekintetében a szerzô, többek között, látensváltozós modellezési eljárással (SEM) vizsgálja a szakirodalmi kutatások eredményeként meghatározott dimenziók direkt és indirekt hatását az érintett területek versenyképességi jellemzôinek leírásánál.

Journal of Economic Literature (JEL) kódok: H41, R11, R13

Kulcsszavak: területi versenyképesség, közszolgáltatások, közjavak, réteghatás

Szabó TAMÁs doktorjelölt, Pécsi Tudományegyetem Közgazdaságtudományi Kar, Regionális Politika és Gazdaságtan Doktori Iskola (levelek@szabotamas.hu). 
Szabó Tamás: A területi versenyképesség és a közszolgáltatások hozzáférhetôségének...

\section{Summary}

One way to define regional competitiveness is to see it as the ability of a region to attract capital to re-settle or counteract population aging and migration. Based on this logic, sustainable competitiveness can be assessed by an analysis of the sustainable infrastructure, the availability of public services and the attractiveness of the environment for life, and the extent to which social contexts influence economic efficiency of the studied areas can be established. This study compares regional competitiveness in four counties in Hungary based on their economic, social and infrastructure features, public services and access to them. The author examines the direct and indirect effects of the dimensions determined as a result of the literature review using, among others, Structural Equation Modelling (SEM) in order to describe the characteristics of competitiveness in the areas concerned.

Journal of Economic Literature (JEL) codes: H41, R11, R13

Keywords: regional competitiveness, public services, public goods, structural equation modelling, layer-effects

\section{KONGEPTUÁLIS KERET}

A területi versenyképesség vizsgálatakor nem hagyható figyelmen kívül, hogy az egyes területeken fellelhetô perspektivikus gazdasági ágazatok alapja az adott térségben fellelhetô humán erőforrás és az azt kiszolgáló infrastruktúra. Az adott terület versenyképességének vizsgálatakor - akár annak gazdasági teljesítményét, akár a gazdaságföldrajzi elônyeit vesszük alapul - fontos látni, hogy mindkét megközelítésben szerepet játszik a humán erőforrás, illetve annak mobilitása és képzettsége (Horváth, 2001).

A kisvárosi versenyképesség értelmezésekor meghatározott „sikerességi faktorok” (Poreisz, 2014:65-79) közül jelen vizsgálat a területek gazdasági, társadalmi szerkezetét és agglomerációs jellemzőit, illetve a közjavak elérhetôségét veszi alapul. Teszi ezt abból kiindulva, hogy a humán erőforrás versenyképességének sajátosságai - a gazdaságföldrajzi jellemzók mentén - alapvetóen a társadalmi közjavak, illetve a közszolgáltatások hozzáférhetôsége alapján írhatók le. Tehát egy terület versenyképessége és a lakosságának életszínvonala között oksági kapcsolat áll fenn, amelynek alapkategóriái között - a munkatermelékenység, a foglalkoztatottság és a jövedelem alapján - függóségi viszony van (Lengyel, 2010:135). Ezt pedig nagyban befolyásolja a rendelkezésre álló képzési, egészségügyi intézmények, illetve a kultúrát szolgáló vagy a további kikapcsolódási lehetôségeket biztosító intézmények hozzáférhetôsége és azok elérhetôsége. „A térségek versenye olyan képesség, amelyik odaragasztja vagy odavonzza a befektetéseket és a tehetséges munkaerôt” (Lengyel, 2010:46). Ebból a logikából következik, hogy a kevésbé versenyképes térségek egyes részei elnéptelenednek, illetve lakónépességük szempontjából elöregedô társadalommal jellemezhetók. 
Ha az egyes térségek a közszolgáltatások tekintetében vett különbözősége és a versenyképesség között arányosságot feltételezünk, akkor feltehetően igaz lesz az a megállapítás, hogy minél kevésbé versenyképes egy térség, annál kisebb lesz a közszolgáltatások igénybevételének intenzitása, következésképpen annak finanszírozási igénye is. Ennek okát nem pusztán a lakónépesség anyagi helyzetében, hanem kulturális igényszintjében és a mobilitási hajlandóságában, lehetôségében is kereshetjük.

\section{A közszolgáltatások fogalmának értelmezése}

A közszolgáltatás fogalommeghatározásának nehézségét annak összetett jellege okozza. Ahogy az az 1. ábrából is kiviláglik, nagyon komplex rendszerrôl van szó, amelyhez az ország állampolgárai túlnyomórészt alanyi jogon kapnak hozzáférést.

\section{1. ábra: Közszolgáltatások Magyarországon}

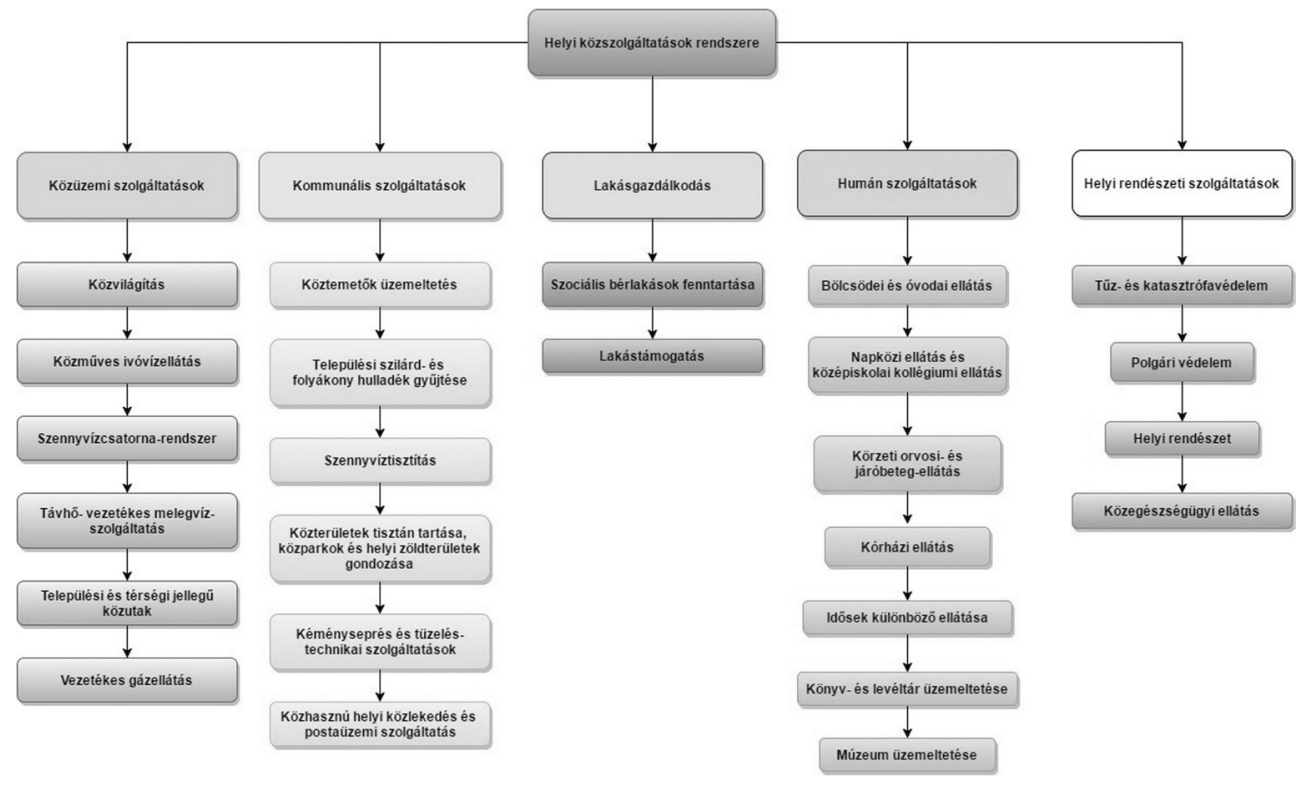

Az 1. ábrán látható a kapcsolódó tevékenységek sajátos, közösségi jellege. Ha a közgazdaság-tudományt hívjuk segítségül a tevékenységi definíció meghatározásakor, Hoffman szerint a közgazdasági tevékenységek fogalomkörébe minden beletartozik, ami nem mezôgazdaság, és nem ipari vagy bányászati tevékenység. E szerint a logika szerint valamennyi közvetlen vagy közvetett hatással bíró gazdasági tevékenység, amely a társadalom széles rétegeinek javait szolgálja, közszolgáltatásnak tekinthető. Ezt a fent hivatkozott szakirodalom tovább szúkíti, mert a szerzô szerint a fenti meghatározást árnyalja a közszolgáltatások közigazgatási háttere, amely szabályozza a tevékenységek tárgyi és személyi feltételeit és a tevékenységek jogi környezetét. „Közszolgáltatás mindazon - ál- 
Szabó Tamás: A területi versenyképesség és a közszolgáltatások hozzáférhetôségének...

lami vagy magánszemélyek által nyújtott szolgáltatás -, amely a lakosok széles körének nyújt valamilyen ellátást, és nem minôsül az állam egyoldalú, közhatalmi aktusának.” (Hoffman, 2009a:25). Horváth a közszolgáltatásokat úgy írja le, hogy azok olyan feladatok ellátására koncentrálnak, amelyek közösségi szervezést igényelnek, és a társadalom tagjai - széles körben meghatározott - szükségleteinek kielégítésére irányulnak. A szerzô külön említést tesz a humán közszolgáltatásokról, amelyeket „jellemzóen az oktatás, egészségügy, szociális juttatások, kulturális közszolgáltatások” (Horváth, 2002:287) köré csoportosítható feladatellátással hoz összefüggésbe. A meghatározásokból kisejlik, hogy a feladatok ellátásához kapcsolódóan komoly technikai és módszertani feltételek társulnak, amelyek követelményként támasztják nem pusztán a személyi és tárgyi feltételek meglétét, hanem jelentős referenciát is megkívánnak az érintett feladatellátás vonatkozásában. A feladatellátáshoz kapcsolódó másik fontos ismérv, hogy a feladatokat állami garanciavállalás mellett, nyilvános közbeszerzési eljárás keretein belül hirdetik meg, amelyek a fentebb meghatározott keret- és peremfeltételek mellett sok esetben anyagi invesztíció vállalását is feltételül szabják. Az ezzel kapcsolatos állami garanciavállalás azt jelenti, hogy az állam az alaptörvényben meghatározott feladatellátási kötelezettség keretein belül szervezi meg az érintett szolgáltatásokat, figyelembe véve az egyenlő hozzáférhetôség lehetőségét, az esélyegyenlőséget.

Mivel egy közjószág esetében - a magánjavakkal ellentétben - egy személynél többre kiterjedôen tartalmaz fogyasztási hatásokat, így annak eredménye is nagyobb volumenben jelentkezik. A közjavak előállítása - akár a tiszta, akár a vegyes közjavakról legyen szó - az állami közhatalom feladata, amelynek a közszolgáltatás keretében történô előállítását az állam jogi úton szabályozza, és szükség esetén finanszírozza. Hoffman értelmezésében a közszolgáltatások szintekre bonthatók, és a kistérséget alsó középszintú, míg a megyét középszintú egységként kezeli. Az ezzel kapcsolatos feladatellátási körök - a közigazgatás új szabályozása szerint - javarészt az érintett szinteken valósulnak meg, figyelembe véve a társadalmi szükségletet és az érintett területi egység gazdasági teherbíró képességét. (Hoffman, 2009a:60).

\section{A közjavak és a területi versenyképesség}

Ahogy a társadalmi közjavak hozzáférhetôsége, úgy az áruk áramlása is helyzetváltoztatáshoz kötött. A mobilitás tehát mind az infrastruktúra - annak gazdasági, fenntarthatósági szempontjai -, mind pedig a humán erőforrás (például egészségügyi, kulturális, nevelési, közlekedési szolgáltatások) szempontjából is fontos versenyképességi tényezőnek mondható. Az elmaradott és fejlett térségek - sok esetben - a közlekedési infrastruktúra jellemzői miatt kerülnek kedvezőbb vagy kedvezôtlenebb helyzetbe akkor, amikor egy beruházás telephelyérôl dönt a befektetô. Ahogy a beáramló tôke befektetéseinek megvalósulásának, úgy a humán erôforrás versenyképességének esetében is, az egyes tértípusokhoz kapcsolódó idôben kifejezett elérhetôségi viszonyok határozzák meg az erôforrások koncentrátumát.

A kormányzati tervek között szereplő északi autópálya meghosszabbítási terveinek megvalósulásával ${ }^{1}$ az északi, illetve az északkeleti megyék versenyképessége - az idó- 
ben kifejezett elérhetôségi relációk javulása miatt - növekedni fog, ugyanis a kényelmesebb és gyorsabb közúti elérhetôség megvalósulása elősegíti az érintett vállalatok szinergikus múködését és a lokális kapcsolatok javulását.

A megyék, mint választott területi egységek, összehasonlítását azok összetett területi szintje indokolja, és ebben a vonatkozásban két szint, a városhálózatok, illetve a kistérségek szintje értelmezhetô. Ugyanis ezeken a szinteken érzékelhetôk azok a mechanizmusok, amelynek nagy része igaz a makroszintú múködésre is. Ugyanakkor fontos megjegyezni, hogy a szakirodalom eltérô mutatók alkalmazását javasolja az egyes eltérố térségi szinteken, ugyanis a területi különbségek jelentôs része nem kimutatható egzakt mutatókkal. A hasonló infrastrukturális kondíciókkal rendelkezô régiók versenyképességi helyzete nagyon eltérô lehet, hiszen a társadalmi tôke hatással van a térségek gazdasági szervezeteinek számosságára és méretére (Fukuyama, 1997).

A területek versenyképességét - sok más mellett - a gazdaságföldrajzi, illetve a közlekedési infrastruktúrája determinálja. Ez a tény ugyan nyilvánvalóvá teszi az autópályával és a vízi közlekedéssel is rendelkezô, nyugatabbra fekvô megye versenyképességi előnyét, amelynek oka fôként a gazdasági koncentráció. Ez a determinisztikus hatás az elmaradott térségeknél is megfigyelhetô, de annak hatásiránya ellentétes. Wallersteinnek (1989) a modern világgazdasági rendszer kialakulásával kapcsolatos modelljében a centrumtérségek - az ismert társadalmi és gazdasági mechanizmusok révén - beavatkoznak a perifériák életébe.

Tekintettel arra, hogy a vállalatok gazdasági teljesítménye, sikeressége vagy sikertelensége sem köthetố egzakt módon, versenyképességi szempontból jól vagy rosszul ellátott térséghez, a területi egységek vizsgálatakor sem hagyhatjuk figyelmen kívül, hogy a megyéken belül a járások is versenyeznek. Ha pedig ezt elfogadjuk, akkor azt is beláthatjuk, hogy az egyes területi egységek (megyék) átlagát nem a homogén tényezók összessége adja. A területi verseny „egy olyan folyamat, amely területi egységek között zajlik, és célja a régióban, városban élók jólétének növelése. A csoportok a helyi politikákon keresztül más térségekkel versengenek, rivalizálnak explicit vagy gyakran implicit módon" (Lengyel, 2003:153). A tényezôvezérelt régiókban a finanszírozások hatékonyságának kiaknázása dominál, ami az árversenyben a költségelônyt helyezi elôtérbe. Ez a közjavak finanszírozásában az elvonást és az azzal kapcsolatos szolgáltatások hiányát - közlekedési járatok és orvosi ellátás -, részleges leépítését, az infrastruktúra túlzsúfoltságát jelenti. Ennek egyenes következménye az ellátás - és vele együtt a személyek versenyképességi esélyének - csökkenése.

Porter felfogása szerint a területi versenyképességet az iparágakra és klaszteresedésre vezeti vissza, a területen élô és/vagy mozgó humán erôforrás számára biztosított társadalmi közjavak hozzáférhetôsége is hozzájárul a versenyző területek sajátosságaihoz. Emellett a területi versenyképességet is befolyásoló innovációs potenciál legfontosabb elemei a technológiai és tudástranszfer, az innovációs szolgáltatások, azaz a tanácsadói tevékenység, valamint az elérhetô adattömeg, a helyi és regionális környezet, úgymint a lakókörnyezet és kulturális szolgáltatások (Rechnitzer-Grosz, 2005). A vizsgálat tárgyát képezó megyék közül az egyik, Nógrád megye közlekedés-földrajzi determinációja nem olyan előnyös, mint Komárom-Esztergom megye e szempont 
Szabó Tamás: A területi versenyképesség és a közszolgáltatások hozzáférhetôségének...

szerinti adottságai. Ugyanakkor a kérdés az, hogy a jól érzékelhetô szállítási korlátai mellett a közjavak igénybevétele, illetve azoknak a városhálózati vagy akár kistérségi szintú hozzáférhetôsége milyen szerkezetet mutat? Nyilvánvaló, hogy a megközelíthetőség az áruk áramlása és a közjavak hozzáférhetôsége révén hat a versenyképességre, de az alapvetô kérdés, hogy ebben a viszonyban az egyes versenyképességet leíró változók között milyen korreláció mutatkozik. Horváth szerint a közlekedés a területi versenyképességet különböző tényezôk sokaságán fejti ki, amelynek eredője a gazdasági szerkezet változásán keresztül hat, ugyanis a regionális munkaerô képzettsége és az oktatási rendszer hatékonysága szorosan kapcsolódik a térségek gazdasági szerkezetéhez (Horváth, 2001).

Erdôsi kellóen árnyalt megfogalmazása, miszerint „a termeléssel és fogyasztással kapcsolatos közlekedési/szállítási szükségletek csak erôsen áttételesen játszanak be a versenyképességet megteremtô folyamatokba (Erdôsi, 2002:141), vitára adhat okot akkor, ha a humán tôke mint versenyképességi tényezô nagyon is fontos eleme a vizsgálat tárgyának. Ugyanis ha a centrum-periféria logikával közelítjük a kérdést, korántsem mindegy, hogy a szórvány- vagy zsákfalvak lakói milyen közszolgáltatási feltételrendszer közepette érik el azokat a közszolgáltatásokat, amelyek képzési vagy kulturális szolgáltatásokon, vagy az egészségügyi ellátáson keresztül közvetlenül hatnak az egyénre, míg az egyénen keresztül közvetetten a versenyképességre.

A területi vizsgálódások során bizonyossá vált, hogy a földrajzi egységek sajátosságai, gazdaságföldrajzi, geopolitikai jellemzôi ún. fóliaként rétegezhetôk a tér minden egységére. Ezeket területpolitikai eszközökkel befolyásolni tudjuk ugyan, de ha erre vállalkozunk, a hazai vonatkozású térértelmezések esetében a legkisebb egység, amit ebben az értelemben relevánsan értelmezni tudunk, az a régió lehet (RechnitzerTóth-Lévai, 2013). Fontos látni - nem tévesztve szem elól a területi relevancia vonatkozását -, hogy az ezeknél kisebb területeknek is megvan a saját, a közszolgáltatásokkal kapcsolatos karakterisztikája. A közszolgáltatások múködésének és hatásmechanizmusának révén ezt a karakterisztikát a közszolgáltatások rétegzôdésében érjük tetten, amely rétegek egymásra rakódva gyakorolnak aggregált hatásokat az adott területen lakó népesség versenyképességére. Tekintettel arra, hogy ezek a rétegek minimum két dimenzióban értelmezendók, egymásra kihatnak, tehát közvetve vagy közvetlenül is éreztetik egymásra, illetve a környezetre gyakorolt hatásukat.

Fleischer szerint az agglomerálódás három pilléren alapszik, amely - a gazdasági, a társadalmi és a környezeti - szempontrendszerek szinergikusan fejtik ki hatásukat, ezzel biztosítva a térségek lakói számára az életük fenntartható fejlődésének lehetôségét (Fleischer, 2004).

A fentiek értelmében könnyen belátható, hogy az olyan közjavak elérhetôsége, amelyek közvetve vagy közvetlenül kapcsolatban állnak az adott terület jóléti tényezôivel, kölcsönhatásban állnak egymással. Erre jó példa lehet egy adott kistérség, megye vagy régió közoktatási, egészségügyi vagy kulturális intézményeinek viszonya a közúti közszolgáltatások igénybevételével. E szerint feltételezhetô tehát, hogy ahol az elóbbiek nagyobb számban találhatók meg, ott az utóbbi nagyobb volumenú megrendelést indukál, és vélhetôen a közszolgáltatások fenntarthatósága is jobb, mint azokon 
a helyeken, ahol csupán az állami kötelezettségvállalást fedi le a szolgáltató. Tekintettel arra, hogy a közszolgáltatások veszteségét az állam köteles téríteni a szolgáltatás végzését ellátó vállalatnak, szocio-ökonometriai jellemzőjüknél fogva, vannak olyan térségek, ahol a közszolgáltatás is kontraszelektíven hat a terület, illetve az ott lakó népesség versenyképességére.

Ebbôl származik a területi esélyegyenlôtlenségi tendencia öngerjesztô folyamata, amely az ismert magyarországi területeken (3H-s térségek) egyértelmúen megfigyelhető. Ugyanakkor a területeken fellelhetô kistérségek versenyképességi hátrányát az is növeli, hogy az agglomerálódó térségekben centrifugális (Fleischer, 2004) migráció figyelhetô meg, ami a versenyképes szaktudással rendelkezô munkavállalók elvándorlását eredményezi. A lélekszám, a közjavakkal való ellátottság esélyegyenlósége felveti a közszolgáltatások finanszírozásának fenntarthatóságával, illetve az egyes területek humán erőforrásának versenyképességével kapcsolatosan azt a kérdést, hogy vajon melyik előbbre való? Differenciálhat-e a költségvetés kontraszelektív módon, pusztán a lakosság demográfiai szerkezete alapján?

Fleischer szerint a természetben és a társadalomban is fellelhetôek ezek a hálózati gócpontok, amely köré az adott területen élô populáció koncentrálódik. Feltételezhetô, hogy az a tendencia, amely szerint az egymással piaci vagy ellátási relevanciában álló gazdasági szereplók a nyersanyagok, illetve a számukra kedvezóbb feltételeket nyújtó gazdaságföldrajzi lokációba orientálódnak, egy térség lakosságára is igaz. Ez egyben komoly migrációs ok is, amely eredményezi többek között azt, hogy a leszakadó térségek aprófalvas települései elöregednek, és a kihalás veszélye fenyegeti az ilyen településeket. Ennek a tendenciának a migrációs oka az, hogy a közjavak és a munkahelyek - amely a versenyképesség alappillérei a népesség szempontjából - súrúbben koncentrálódnak a térben. A fôváros körül kialakult agglomerációs zónában a népességszám megsokszorozódott. A nagyvárosok körüli koncentráció figyelhetô meg Székesfehérvár, Veszprém, Gyôr, Pécs, Szeged és Miskolc körül, valamint a Balaton környékének esetében is. Ezen városok környéke az elvándorlásból tudta növelni a népességszámát (Huzdik, 2014). A népesség pozitív növelésének okai között gazdasági és mobilitási elônyök szerepelnek motiváló eszközként.

\section{A VIZSGÁlAT MÓDSZERTANÁRÓL}

A rejtett változós modellezés a társadalomtudományok kutatásában nagy népszerúségnek örvend. Ennek oka, hogy az eljárás segítségével a vizsgált adatsorokban nem pusztán a közvetlenül mérhetô hatások mutathatók ki, hanem azok is, amelynek relevanciáját rejtett változók egymásra hatása ír le. Ilyen lehet például a területi versenyképesség vizsgálatakor a közszolgáltatások finanszírozása, illetve a közjavak hozzáférhetôségének kérdése. Ha axiómaként tekintjük, hogy a humán fejlettségi index (Human Development Index) vagy a humán tôke (Human Capital) hatással van a területi versenyképességre, akkor az is bizonyosnak vehetô, hogy a humán szolgáltatásokkal kapcsolatos közjavak hozzáférhetôsége és azok finanszírozásának intenzitása - a humán tôkén keresztül - determinálja egy terület versenyképességét. A modell felállí- 
Szabó Tamás: A területi versenyképesség és a közszolgáltatások hozzáférhetôségének...

tása során feltételezzük, hogy az egyes változók között oksági viszony van, és azoknak a viszonya strukturálisan felírható. Ezeket a kapcsolatokat a modell felállításakor is figyelembe vesszük.

Ennek alapján két csoportba sorolhatjuk a kiválasztott változókat, amelyek lehetnek külsố vagy belsố változók. A modellben azok a tényezôk, amelyekre nem hat más változó, külsô (exogén) tényezóknek nevezzük. Azokat a változókat pedig, amelyekre a modellben specifikált tényezôk közül külsố hatás hat, belsô (endogén) tényezônek mondjuk. A modell futtatásakor ezekkel a külsố és belsố tényezôkkel operál a modellalkotó program, amely a változók közötti direkt és indirekt kapcsolatokat írja le. A modell használja az útvonalelemzési eljárást az egyes változók közötti oksági viszony megléte mellett, amely viszonyokat a program regressziós egyenletekkel kapcsolja öszsze. A szokásos látensváltozós eljárásokhoz képest annyival több a módszer, hogy alkalmazása során a modell illesztésekor ezt a strukturális viszonyt vesszük figyelembe. A látensváltozós modellezés (SEM) egy olyan matematikai eljárás, amelyben változókon egyidejưleg több múvelet fut, mint például a faktoranalízis és a többváltozós regresszió. Ennek eredményei magyarázzák a gráfok csúcsain lévô változókat, az éleken pedig jelölik a regressziós együtthatókat.

A modellben szereplő adatsorok 1970 és 2014 közötti idôsoros adatokat tartalmaznak, amelyek négy megyére ${ }^{2}$ vonatkoznak a mobilitáshoz, az érintett terület lakosságához és gazdaságához kapcsolódva, az 1. táblázat szerint. Az adatsorok megyénként, évekre vonatkoztatottan aggregálva kerültek a modellbe. A politikai kurzusváltások statisztikai módszertani eltérései által okozott adatsorhiányokat bilineáris interpolációs eljárás segítségével töltöttem fel. Figyelembe véve az adatsorok dimenziójának különbözôségét és a számos skálázási lehetôséget, a modell futtatása előtt a fenti eljárások után kapott mátrixon z-standardizálást végeztem annak érdekében, hogy az adatok azonos értelmezési tartományba kerüljenek. A modellben területi adottságként kezeltem az infrastrukturális dimenziót, amelybe a táblázatban ismertetett változókat emeltem be.

Figyelembe véve, hogy ezek statikus faktorok, külsố változóként kezeltem a modellben, amely a korábban említett irodalmak szerint a humán tôke fejlesztése révén hat a területi versenyképességre.

A vizsgálat eredményei

Az adatsorokban szerepeltek a közoktatási intézményekre vonatkozó finanszírozási és férôhelyadatok, illetve az egészségügyi és szociális támogatások nagyságára vonatkozó adatok. Ebból a szempontból erős kapcsolatot mutat a versenyképességgel az összes megye tekintetében, kivéve Vas megyét. A viszonylagos gyengeség e helyütt magyarázható a határ közelségéből fakadó, kevésbé erős támogatási intenzitással. Az egészségügyi és szociális támogatások intenzitásának gyenge a versenyképesség-szempontú magyarázó ereje, mert Komárom-Esztergom megye és Heves megye vonatkozásában az értékek oksági viszonyt mutatnak ugyan, de a másik két megyepár esetében nem bírnak magyarázó erôvel ezek a változók. Az infrastruktúra dimenzióértékének ver- 
senyképesség szempontjából mutatott viszonylag gyenge oksági kapcsolatát az utóbb említett változók gyenge értéke rontja. Ha a fent említett társadalmi hatásoktól megtisztítanánk az adatsort, vélhetôen az infrastruktúra-dimenzió és versenyképesség kapcsolata erósebb lenne. Ezt erôsítik a modell futtatása után eredményként kapott, dimenziókra vonatkozó konzisztenciamegbízhatósági eredmények, amelyet a 2. táblázat szemléltet.

\section{1. táblázat: A modellben alkalmazott mutatók}

\begin{tabular}{|c|c|c|}
\hline Variables & Változó & Dimenzió \\
\hline BusT & Férôhely-kihasználtság a közhasznú közúti közlekedésben & \multirow{4}{*}{$\begin{array}{l}\text { Mobilitási } \\
\text { képesség }\end{array}$} \\
\hline CarN & Autók száma & \\
\hline PlaceNH & $\begin{array}{l}\text { Államilag finanszírozott férôhelyek száma a közhasznú } \\
\text { közúti közlekedésben }\end{array}$ & \\
\hline Road & Közúti fejlesztésre és/vagy fenntartásra kapott dotáció & \\
\hline CuSoEnt & $\begin{array}{l}\text { Kulturális, szociális, szabadidôs tevékenységek fejlesztésé- } \\
\text { vel foglalkozó intézmények dotációja }\end{array}$ & \multirow{2}{*}{ Intézményi } \\
\hline Health\&Soc. & Egészségügyi és szociális támogatás összege & \\
\hline EnterP & Vállalkozások & \multirow{3}{*}{ Gazdasági } \\
\hline GDP & GDP & \\
\hline IpariTerm & Ipari termelés & \\
\hline AbleToWork & Munkaképes korúak & \multirow{2}{*}{ Emberi tényezôk } \\
\hline Population & Lakónépesség & \\
\hline
\end{tabular}

Forrás: Saját szerkesztés SmartPLS alapján

2. táblázat: A modell dimenzióinak konzisztenciamegbizhatósága $a^{3}$

\begin{tabular}{l|r}
\hline Composite Reliability & Confidence Intervals \\
\hline Mean, STDEV, T-Values, P-Values & Original Sample (0) \\
\hline Mobilitási képesség & 0,832 \\
\hline Területi versenyképesség & 0,924 \\
\hline Gazdasági tényezôk & 0,858 \\
\hline Humán tényezốk & 0,997 \\
\hline Épített környezet & 0,618 \\
\hline
\end{tabular}

A gazdasági dimenzióba vitt változók esetében gyenge magyarázó erốt mutat ( 0,5-0,6 között szóródik) az ipari termelés volumene, míg ettől némileg erôsebbet a GDP. A területi versenyképesség szempontjából - a modell értékei szerint - erôs 
Szabó Tamás: A területi versenyképesség és a közszolgáltatások hozzáférhetôségének...

magyarázó erôvel bír a múködó vállalkozások száma. Nem okoz meglepetést a területet jellemzô humán változók (munkaképes korúak és az össznépesség) által mutatott erôs szignifikancia, viszont annál érdekesebb, hogy a versenyképesség szempontjából a humán jellemzók dimenziója indirekt hatású. A mobilitásiképesség-dimenzió esetében nagyjából hasonló magyarázóértékeket kapunk, és területi versenyképességi szempontból erôs indirekt hatásra figyelhetünk fel, amelynek egyik lehetséges oka a munkaképes életkorúak belsô migrációja. Ezt erôsíti a közhasznú közúti közlekedés finanszírozásában, illetve a személygépjármúvek számának a mobilitás szempontjából mutatott indirekt hatása. Ez az eredmény alátámasztja, hogy a korábban leírt, a versenyképességi tényezôk aggregátumaként értelmezett „rétegek” keresztmetszeti torzulását - többek között - a távolságok, illetve az egyes intézmények elérhetôségének különbözôsége okozza.

A térbeliség fogalmának magyarázatára számos példát találunk, de jelen vonatkozásban - a gazdasági mellett - nagy szerepet kap a szociális távolság, mint a társadalmi egyenlôtlenség mértéke (Erdôsi, 2013). Fontos látni, hogy a kettô között ok-okozati összefüggés van, és a társadalmi javak, valamint a jólét viszonyában a kölcsönhatás öngerjesztô folyamat, akár negatív, akár pozitív értelemben. Ezen a ponton a társadalmi és a gazdasági távolság fogalma összekapcsolódik, hiszen a közforgalmú közlekedés - mint a humán eróforrás mobilitását biztosító infrastruktúra és szolgáltatások halmaza - részese az olyan közjavak, mint az oktatás, egészségügyi ellátás, kultúra stb. hozzáférhetôségének biztosításának.

\section{ÖsszegzÉS}

A cikkben kifejtett területi réteghatás a közjavak finanszírozásán és az érintett lakónépesség versenyképességén keresztül gyakorolt spillover hatás. Ez a hatásmechanizmus nem pusztán a szektoriális szerkezetre, hanem a rendelkezésre álló infrastruktúrán keresztül az életszínvonalra is kihat. A területi réteghatás a közjavak és közszolgáltatások összességének jellemzőin keresztül fejti ki hatását, amely annyiban különbözik a telephelyelméletből ismert centrum-periféria jelenségtôl, hogy ez esetben a javak koncentrációját egy területen élố népesség preferenciája végzi ugyan, de ez nem minden esetben tiszta (üzleti) döntés, mert az egyén - szemben egy tókével rendelkezô vállalattal - sok esetben gazdasági kényszerpályán mozog, amely korlátozza a döntéseiben. Ezért a nemzetgazdasági és területfejlesztési törekvések között prioritást kell hogy élvezzen az egyes területi relációk hálózatszerú, határokon átnyúló versenyképesség-javítása, továbbá a hálózatból kimaradó térségek fejlődési folyamatba való bekapcsolása. Ennek megoldása olyan speciális gazdaságfejlesztési törekvéseken keresztül képzelhetô el, amelynek a motorja a helyi kis- és középvállalkozások szinergiáját állítja középpontba. Ezzel párhuzamosan indokolt lenne a közszolgáltatások karakterisztikájának területi szempontú hatásvizsgálata, illetve folyamatos monitorozása, mert a közigazgatási rendszer reformjával nemcsak az intézmények alakultak át, hanem az ügyintézési lokációk és súlyok is megváltoztak. 


\section{JEGYZETEK}

1 Kassa és Pozsony városát elérô, továbbá a komáromi új Duna-híd és az Ipoly-hidakkal kapcsolatos közúti infrastruktúra-fejlesztés.

2 Komárom-Esztergom, Heves, Nógrád és Vas megye.

3 Forrás: SmartPLS - bootsraping out-put.

\section{FELHASZNÁLT IRODALOM}

Erdősi Ferenc (2002): Gondolatok a közlekedés szerepérôl a régiók/városok versenyképességének alakulásában. Tér és Társadalom, 16. évf., 1. sz., 135-159.

Erdôsi Ferenc (2013): A távolságfogalmak értelmezése és alkalmazásuk. Tér - Gazdaság - Ember, 1. évf., 3. sz.

Fleischer Tamás (2004): Kistérségi fejlôdés, közlekedés, fenntarthatóság. Közlekedéstudományi Szemle, 54. évf., 7. sz., 242-252.

Fukuyama, Francis (1997): Bizalom. A társadalmi erények és a jólét megteremtése. Európa Könyvkiadó, Budapest.

Hair, Joseph F. et al. (2013): A primer on pratial least squares structural equation modeling (PLS-SEM). SAGE Publications Inc., Washington D.C.

Hoffman István (2009): Az önkormányzati közszolgáltatások szervezése és igazgatása az elmélet és a gyakorlat tükrében. ELTE Eötvös Kiadó, Budapest.

Horváth Gyula (2001): A magyar régiók és települések versenyképessége az európai gazdasági térben. Tér és Társadalom, 15. évf., 2. sz., 203-231.

Horváth M. Tamás (2002): Helyi közszolgáltatások szervezése. Dialog Campus Kiadó, Budapest-Pécs.

Horváth M. Tamás (2010): Közmenedzsment. Dialog Campus Kiadó, Budapest-Pécs.

Huzdik Katalin (2014): Migrációs potenciál alakulása, és az azt befolyásoló tényezók a XXI. század elsô évtizedében Magyarországon. PhD-dolgozat, Szent István Egyetem, Gödöllô.

Katona Tamás (2014): A területi felzárkózás dilemmái. SZTE Gazdaságtudományi Kar, Szeged.

Lengyel Imre (2010): Regionális gazdaságfejlesztés. Akadémiai Kiadó, Budapest.

Lốcsei Hajnalka - Szalkai Gábor (2008): Helyzeti és fejlettségi centrum-periféria relációk a hazai kistérségekben. Területi Statisztika, 48. évf., 3. sz.

Poreisz Veronika (2014): Versenyképességi modellek alkalmazhatósága kisvárosokra. SZTE Gazdaságtudományi Kar, Szeged.

Rechnitzer János - Grosz András (szerk.) (2005): Régiók és nagyvárosok innovációs potenciálja Magyarországon. MTA-RKK, Pécs-Gyôr.

Rechnitzer János - Tóth Tamás - Lévai András (2013): Regionális versenyképesség Kelet-Közép-Európában. Tér - Gazdaság - Ember, 1. évf., 4. sz. 